\title{
GENERAL BEHAVIOR AND VEGETATION ASSOCIATED WITH THE HABITATS OF ASSAMESE MONKEY (Macaca assamensis McClelland, 1840) ALONG KALIGANDAKI RIVER BANK, WESTERN NEPAL
}

\section{Pavan Kumar Paudel and Mukesh Kumar Chalise}

Journal of Institute of Science and Technology

Volume 22, Issue 1, July 2017

ISSN: 2469-9062 (print), 2467-9240 (e)

Editors:

Prof. Dr. Kumar Sapkota

Prof. Dr. Armila Rajbhandari

Assoc. Prof. Dr. Gopi Chandra Kaphle

JIST, 22 (1): 110-119 (2017)

Voltume $22 \quad$ Issie $1 \quad$ July 2017

JOURNAL OF INSTITUTE OF

SCIENCE AND TECHNOLOGY

Published by:

Institute of Science and Technology

Tribhuvan University

Kirtipur, Kathmandu, Nepal

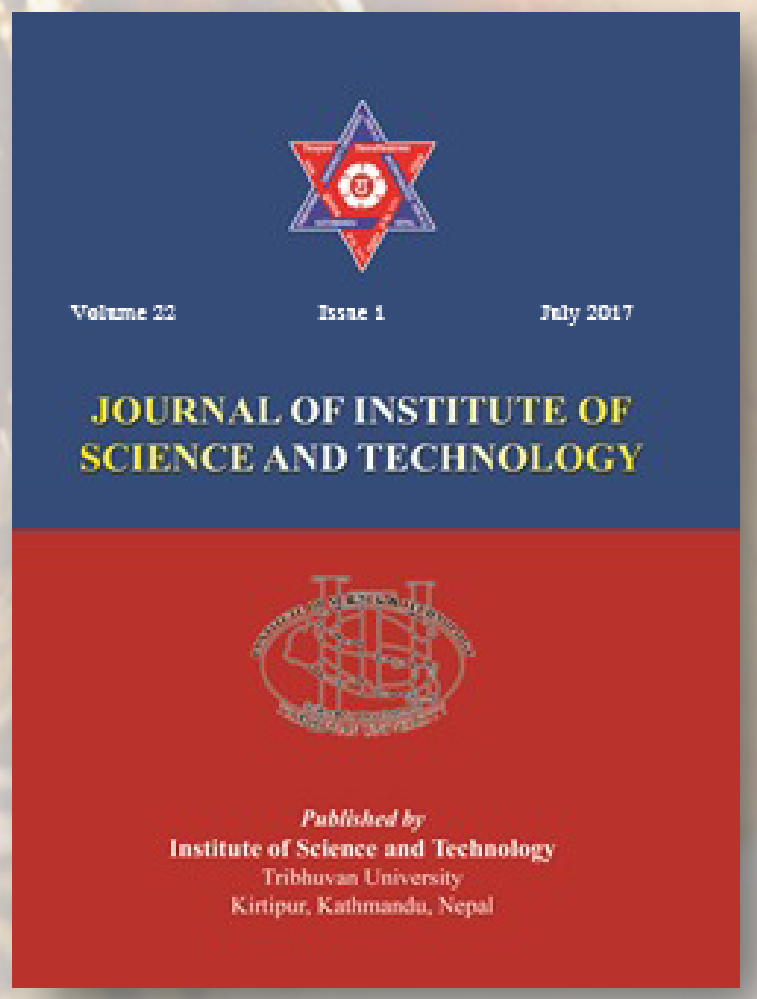




\title{
GENERAL BEHAVIOR AND VEGETATION ASSOCIATED WITH THE HABITATS OF ASSAMESE MONKEY (Macaca assamensis McClelland, 1840) ALONG KALIGANDAKI RIVER BANK, WESTERN NEPAL
}

\author{
Pavan Kumar Paudel* and Mukesh Kumar Chalise \\ Central Department of Zoology, Tribhuvan University, Kirtipur, Nepal \\ *Corresponding E-mail: pavanreturn@gmail.com
}

\begin{abstract}
This study was focused on Macaca assamensis general behavior and vegetation associated with their habitats in Kaligandaki River Basin at Baglung and Parbat Districts of Nepal. The field survey was conducted from December, 2015 to May, 2016 to explore the Assamese Macaque general behavior and vegetation associated with their habitats. Total area of $104.70 \mathrm{~km}^{2}$ was surveyed, vegetation analysis was done by random quadrates sampling method and behavioral data were collected by scan sampling method. A total of 47 individuals of Assamese Macaques (Macaca assamensis) were counted in four different troops. Total of 2240 scan samples were recorded from the four different troops during this study period the scan samples revealed that foraging was $47 \%$, moving $28 \%$, resting $14 \%$ and grooming $11 \%$. In the context of daily activity pattern for aging time of Assamese monkey was found to be highest 54\% in 15:00 to 18:00 observational phase and lowest $40 \%$ in the observational phase of 12.00 to 15.00 hours. Moving time of the Assamese monkey was found to be highest $33 \%$ in 12.00 to 15.00 observational phase and lowest $22 \%$ at 15:00 to 18:00 observational phase, resting time of Assamese monkey was found to be highest 15\% in 09:00 to $12: 00$ hours and lowest 13\% in 15:00 to 18:00 observational phase and Assamese monkey were seen mostly grooming $13 \%$ in 12.00 to 15.00 hours and lowest 10\% in 15:00 to 18:00 observational phase. By quadrate sampling, 58 plant species with 716 number were recorded. Sal (Sorea robusta) was the dominant plant species with relative density $31.42 \%$ and relative frequency $8.376 \%$ which was followed by Tiju (Diospyros malabarica) with relative density $10.93 \%$ and relative frequency $8.376 \%$.
\end{abstract}

Keywords: Macaca assamensis, Quadrate, Scan sampling, Vegetation, Western Nepal.

\section{INTRODUCTION}

Assamese monkeys inhabit in the mountains and hills along the Himalayas. This species has been reported from Nepal, India (Medhi et al., 2007), Bhutan (Kawamoto et al., 2006) Myanmar, Bangladesh (Menon, 2003; Chalise, 2011) Thailand, Southernmost China and Laos (Zhou et al., 2011; Timmins \& Duckworth, 2013). It was recorded from North Thailand ranging $610 \mathrm{~m}$ to $1830 \mathrm{~m}$ asl (Sanjaya et al., 2003). Chalise (2013) recorded it from $380 \mathrm{~m}$ in Mulghat, Tamor to $2350 \mathrm{~m}$ asl in Langtang, Nepal. It was reported to cover wider geographical ranges, with fragmented population, distributed along rivers in the tropical and subtropical areas. The reported areas covered Kankai valley of Ilam, Sabhaya Valley and its range further extended west to Makalu Barun National Park, Melamchi, Langtang National Park (Chalise, 2003), Nagarjun Area of Shivapuri Nagarjun National Park, Makwanpur, Dhading,
Myagdi, Ramdi, Palpa, Achham district (Chalise, 2003 \& 2008; Wada, 2005), Baglung and Parbat (Paudel, 2016b \& 2016c; Paudel \& Chalise, 2016) to Chamelia river basin (N 29'48'34.6', E 8051'02.8', 1607m) of Api Nampa Conservation Area (Chalise, 2013). Assamese monkeys have been categorized as endangered species by International Union for Conservation of Nature (IUCN) Red list category and one of the protected species by National Parks and Wildlife Conservation Act 1973 due to the low population and conservation threats (Janawali et al., 2011). They are kept as Appendix II of Convention on International Trade in Endangered Species (CITES) (Chalise, 2013).

Behavior is the response of both the physical as well as habitat condition of animals (Sarkar, 2000). It varies from habitat to habitat depending upon the resource distribution. In primate, food, mates, drink and roosting trees are the most important resources, 
which control activities. Among these resources, food seems to be the most crucial primary factor which regulates day-to-day activity profiles (Sarkar et al., 2012). So, the study of animal behavior is of great practical importance for the conservation of wild animals in their natural habitats (Manning \& Dawkins, 1998).

\section{MATERIALS AND METHODS \\ Study area}

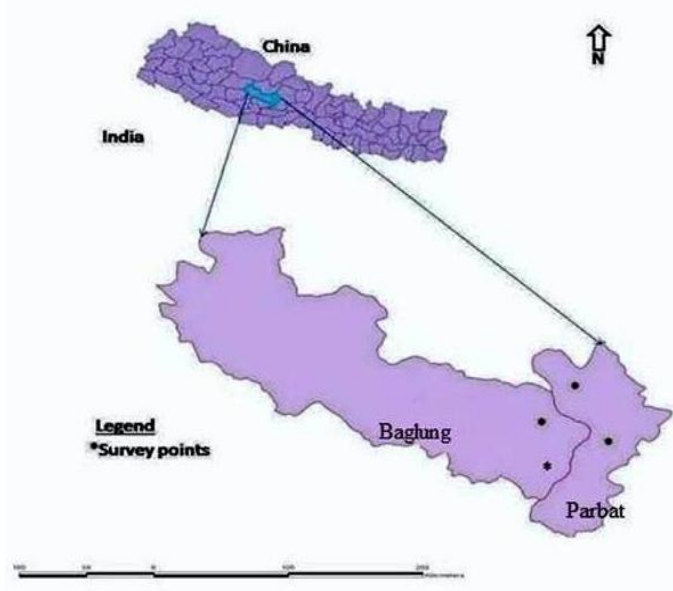

Fig. 1. Study area and sites in the map of Nepal.

The study was carried out in Baglung and Parbat districts of Dhawalagiri Zone; it lies in the Western development region of Nepal. The district Baglung is a part of Province No. 6, with its district headquarters Baglung, and the district Parbat is a part of Province No. 4 and one of the seventy five districts of Nepal with its district headquarter Kushma. The study mainly conducted at the Kaligandaki river basin, covering 11 VDC's study area extended between $83^{0} 35^{\prime} 29.2^{\prime \prime}$ to $83^{\circ}$ $35^{\prime} 72^{\prime \prime}$ 'East longitude and $28^{\circ} 05^{\prime} 24.2^{\prime}$ ' to $28^{\circ} 19^{\prime}$ 45 " North latitude and elevation ranges between $560 \mathrm{~m}$ to $1650 \mathrm{~m}$ asl. The total population of the study area within 11 VDC's was 37,153and the total households was 8,949 (Census report, 2011).

Total research site area of Baglung site VDCs is $71.3452 \mathrm{~km}^{2}$ and Parbat site VDCs is $33.357 \mathrm{~km}^{2}$. The study area lies in between tropical to temperate belt of Nepal. This study area has a unique geographical feature having both North and South facing topography. The rain-bearing wind from the Bay of Bengal blows from the east towards west of Nepal during the rainy season. The climate of study area and its vicinity is mainly dry and wet. The average maximum temperature was recorded $\left(27.70^{\circ} \mathrm{C}\right)$ and minimum temperature was recorded $\left(15.30^{\circ} \mathrm{C}\right)$ (Source: NG/ RDHM Pokhara). According to the climatic data, average monthly relative humidity at morning was $77.17 \%$ and at evening was $78.15 \%$. Highest precipitation was recorded $(553.6 \mathrm{~mm})$ in the month of July during the study period, while no precipitation was recorded in the months of November and December (Source: NG/ RDHM Pokhara). Study area is rich in biodiversity which may be due to presence of alluvial soil along the basin of this large Kaligandaki River, and high productivity of tropical deciduous riverine forest (Chalise, 2013). In broad classification, the study area falls in SoreaDiospyros zone (Paudel, 2016a). Mixed type of forest was found in the study area. Tropical deciduous riverine forest sub-tropical grassland and sub-tropical evergreen forest are the forest types in the study area (Chalise, 2013).

\section{Block design}

To study the Assamese monkey, study area were divide into four blocks namely Block A (Chisti, Jaidi, Arjewa and Binamare VDCs), Block B (Kusmisera, Amalachaur and NarayansthanVDCs), Block C (Siwalaya and Pang VDC) and Block D (Nangliwang and Dhairing VDCs). Blocks are designed on the basis of habitat character (Rijal, 2014). Which were separated by large Kaligandaki river i.e. Block $\mathrm{A}$ and $\mathrm{B}$ from Baglung district site where as Block C and D from Parbat District site.

\section{General behavior}

Behavioral data were obtained by the scan sampling method. The behaviors of monkey were recorded for two minute at interval of 10 minutes (Altman, 1974; Martin \& Boteson, 1993; Chalise, 1997) with the help of timer aided by binoculars. Scan samples were recorded covering all four distinct time period viz. early morning, late morning, afternoon and evening. Other events and interesting behaviors of any members of the groups were also recorded whenever noticed. The animals were observed daily from 06:00 A.M. to 18.00 P.M. The daily observation schedule was divided into four shifts; early morning shift: 06.00-09.00 hr. late morning shift: $09.00-12.00 \mathrm{hr}$. afternoon shift: 12.00-15.00 hr. and evening shift 15.00-18.00 hr. Once in a week continuous 12 hourly observations was undertaken with the help of field assistance. Direct ocular observation method was employed for cataloguing the behavior. The ocular observation was aided with $10 \times 40 \mathrm{~mm}$ binoculars. Following behaviors were observed including other social 
activities of Assamese Macaques in the study area. Below mentioned description from Chalise (2003) was used to distinguish the behaviors among troops.

I. Foraging: The behavior activity in which monkey searches for food or wanders in search for food including eating any substance, licking stone, drinking water and slight movement in search of food.

II. Moving: The behavioral phenomenon in which monkey produces motion displacing from one place to another.

III. Resting: The state when Assamese rest with the body supporting upon the buttocks with hind quarters lowered on to a supporting surface.

IV. Grooming: The behavioral phenomenon in which monkeys search their own fur or the fur of others for lice, bugs or diet which include rubbing, licking and scratching.

\section{Habitat analysis}

Due to the mountainous topography that precludes most of the systemic survey methods (Ross \& Reeve, 2003), quadrate sampling by using the quadrates of $20 \times 20 \mathrm{~m}$ sized were done to analyze vegetation of Assamese monkey habitat. Total 21 quadrates were laid down randomly in the possible habitat of macaques. 11 quadrate were laid down in Baglung site where as 10 quadrate were laid down at Parbat site (Figure 2). Species diversity of trees was calculated. The collected vegetation data were quantitatively analyzed. To understand characteristics and productivity of the habitat, different parameters like density, relative density, frequency, relative frequency and dominance were determined (Zobel et al., 1987). Local name of the plant was identified by the experienced local person. Unidentified plants in the field were prepared herbarium and were identified at National Herbarium Center, Godawori, Lalitpur.

$$
\text { Density of a species }=\frac{\text { Total no. of individuals of a species }}{\text { Total no.of quadrates } \mathrm{x} \text { Area of a quqdrqte }}
$$$$
\text { Relative density of a species }=\frac{\text { Density of a species }}{\text { Total Density of all species }} \times 100
$$

Frequency of a species is the percentage of quadrates in which the particular species occurs. It gives an index on the spatial distribution of a species and is a measure of relative abundance (Krebs, 1978).

$$
\text { Frequency of a species }=\frac{\text { No. of quadrate in which of a species occurs }}{\text { Total no.of quadrates }} \times 100
$$$$
\text { Relative Frequency of a species }=\frac{\text { Frequency value of species }}{\text { Total frequency value of all species }} \times 100
$$

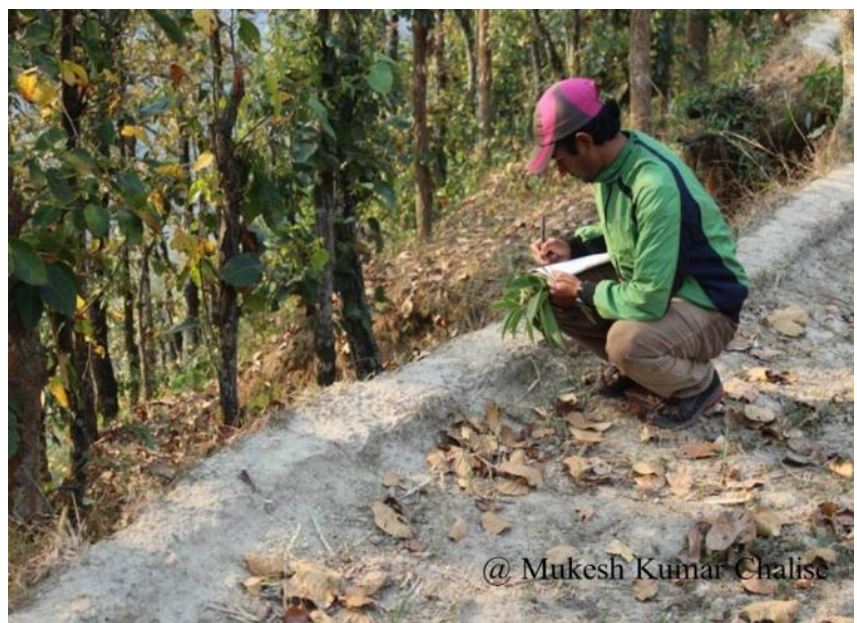

Fig. 2. Vegetation analysis.

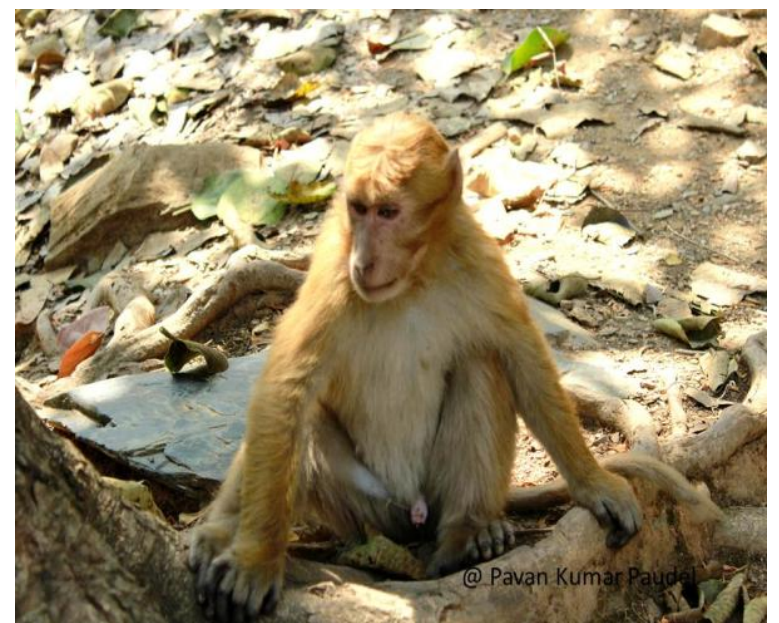

Fig. 3. Adult male Assamese Monkey. 


\section{RESULTS}

\section{General behavior}

In the study site a total of 47 individuals of Assamese Macaques (Macaca assamensis) were counted in four different troops during the field study dated from December, 2015 to May, 2016. The minimum numbers of Assamese Macaques were reported from the Balewa troop of Amalachaur VDC whereas maximum numbers of Assamese Macaques were reported in Aduwabari troop of Chisti VDC.

Field work was carried out from Janauary to April, 2016. Total jungle time was of 345 hours and animal contact time was 185 hours. Four major behaviors (foraging, moving, resting and grooming) were recorded during the study period. Behavioral data were obtained by the scan sampling method. Total of 1640 scan samples were recorded from all four troops. The animals were observed daily from 06:00 AM to 18.00 PM. Daily observation schedule was divided into four shifts; early morning shift: 06.00-09.00 hr. late morning shift: 09.00-12.00 hr. afternoon shift: $12.00-15.00 \mathrm{hr}$. and evening shift 15.00-18.00 hr. Once in a week continuous 12 hourly observations was undertaken with the help of field assistance. Direct ocular observation method was employed for cataloguing the behavior. The ocular observation was aided with $10 \times 40 \mathrm{~mm}$ binoculars. The scan sample revealed that foraging was $47.25 \%$, moving $27.25 \%$, resting $14 \%$, grooming $11.5 \%$ (Figure 4).

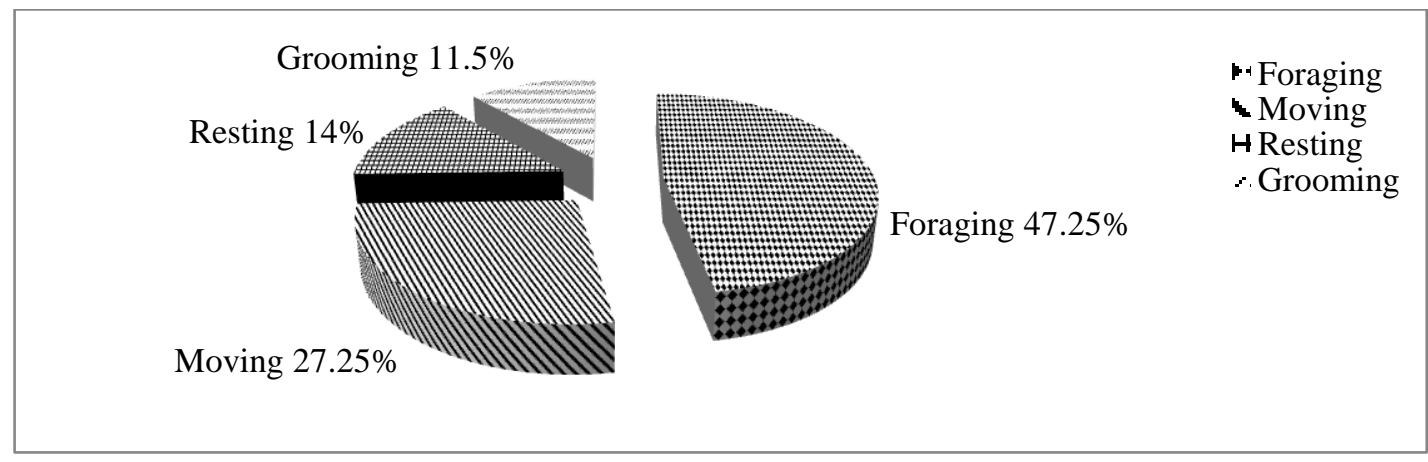

Fig. 4. General behavior of Assamese Macaques in Kaligandaki river bank of Western Nepal 2016.

\section{Diurnal activity pattern}

Foraging time of the Assamese monkey was found to be highest $54 \%$ in 15:00 to 18:00 observational phase followed by $50 \%$ in the morning from 06:00 to 09:00 observational phase, $43 \%$ in $09: 00$ to 12.00 observational phase and $40 \%$ in the observational phase of 12.00 to 15.00 hours. Moving time of the Assamese monkey was found to be highest $33 \%$ in 12.00 to 15.00 observational phase followed by $30 \%$ in 09:00 to $12: 00$ observational phase, $24 \%$ in $06: 00$ to $09: 00$ observational phase and $22 \%$ in $15: 00$ to 18:00 observational phase. Resting time of Assamese monkey was found to be highest 15\% in 09:00 to 12:00 hours followed by $14 \%$ in $06: 00$ to $09: 00$ and 12.00 to 15.00 hours, $13 \%$ in $15: 00$ to $18: 00$ observational phase. Assamese monkey were seen mostly grooming $13 \%$ in 12.00 to 15.00 hours, $12 \%$ in 09:00 to 12:00 observational phase, $11 \%$ in 09:00 to $12: 00$ observational phase, and10\% in $15: 00$ to 18:00 observational phase (Figure 5).

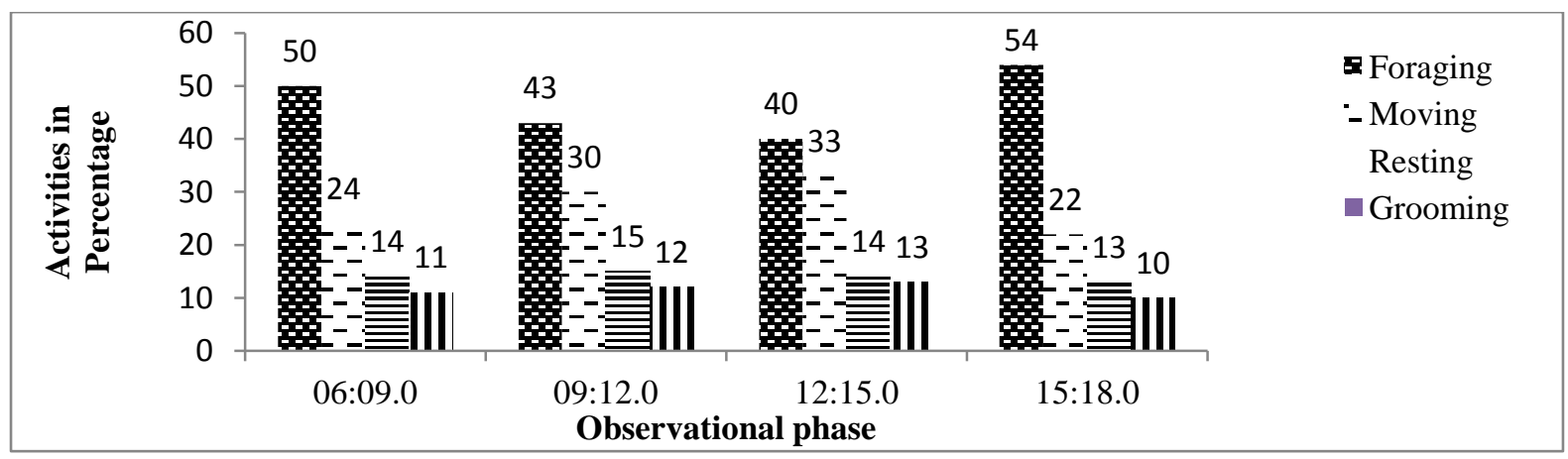

Fig. 5. Diurnal activity pattern of Assamese Macaque in Kaligandaki river bank Western Nepal 2016. 


\section{Vegetation analysis}

Quadrates of $20 \mathrm{~m} \times 20 \mathrm{~m}$ size were laid down in the main habitat of Assamese Macaques to analysis the habitat. By quadrate sampling, 58 plant species with 716 number were recorded. This study revealed that Sal (Sorea robusta) is the dominant plant species with relative density $31.42 \%$ and relative frequency $8.38 \%$ which is followed by Tiju (Diospyros malabarica) relative density $10.93 \%$ and relative frequency $8.38 \%$. The details of vegetation is given in (Table 1).

Table 1. Value of different parameters for tree species in the study area.

\begin{tabular}{|c|c|c|c|c|c|c|c|}
\hline S.N. & $\begin{array}{l}\text { Common } \\
\text { Name }\end{array}$ & Scientific Name & Total & Density & $\begin{array}{l}\text { Relative } \\
\text { Density }\end{array}$ & Frequency & $\begin{array}{l}\text { Relative } \\
\text { Frequency }\end{array}$ \\
\hline 1 & Sal & Sorearobusta & 208 & 0.0204 & 31.42 & 85.71 & 8.376 \\
\hline 2 & Chilaune & Schimawallichii & 56 & 0.0055 & 8.47 & 66.66 & 6.514 \\
\hline 3 & Aap & Mangiferaindica & 14 & 0.0013 & 2.002 & 28.27 & 2.762 \\
\hline 4 & Ghokre & & 10 & 0.0009 & 1.386 & 23.80 & 2.325 \\
\hline 5 & Kutmiro & Litseamonopelata & 3 & 0.0002 & 0.308 & 9.52 & 0.930 \\
\hline 6 & Khanyo & Ficussemicordata & 41 & 0.0040 & 6.162 & 33.33 & 3.257 \\
\hline 7 & Jamun & Syzigiumcumini & 14 & 0.0013 & 2.002 & 38.09 & 3.722 \\
\hline 8 & Aamala & Phyllanthusemblica & 5 & 0.0004 & 0.616 & 9.52 & 0.930 \\
\hline 9 & Tiju & Diospyrosmalabarica & 73 & 0.0071 & 10.93 & 85.71 & 8.376 \\
\hline 10 & Kaligede & & 13 & 0.0009 & 1.386 & 23.80 & 2.325 \\
\hline 11 & Tuni & Toonaciliate & 11 & 0.0010 & 1.540 & 47.61 & 4.652 \\
\hline 12 & Pakhuri & Ficus spp. & 3 & 0.0002 & 0.308 & 9.52 & 0.930 \\
\hline 13 & Mahuwa & Engelhardiaspicata & 29 & 0.0028 & 4.467 & 42.85 & 4.187 \\
\hline 14 & Belauti & Psidiumguajava & 29 & 0.0028 & 4.467 & 14.28 & 1.395 \\
\hline 15 & Saj & Terminaliaalata & 6 & 0.0005 & 0.770 & 19.04 & 1.860 \\
\hline 16 & Bhorla & Bauhiniaavahlii & 8 & 0.0007 & 1.078 & 19.04 & 1.860 \\
\hline 17 & Thulogabajo & & 4 & 0.0003 & 0.462 & 19.04 & 1.860 \\
\hline 18 & Mel & Pyruspashia & 1 & 0.00009 & 0.138 & 4.76 & 0.465 \\
\hline 19 & Sindure & Bixa orelana & 1 & 0.00009 & 0.138 & 4.76 & 0.465 \\
\hline 20 & Pipal & Fecus religiosa & 1 & 0.00009 & 0.138 & 4.76 & 0465 \\
\hline 21 & Dhairo & Woodfordiafruticosa & 22 & 0.002 & 3.081 & 38.09 & 3.722 \\
\hline 22 & Aakhitare & & 6 & 0.0005 & 0.770 & 14.28 & 1.395 \\
\hline 23 & Pakhuri & Ficusglaberrima & 3 & 0.0002 & 0.308 & 4.76 & 0.465 \\
\hline 24 & Bas & Bambusa spp. & 6 & 0.0005 & 0.770 & 23.80 & 2.325 \\
\hline 25 & Dabdabe & Garugapinnata & 10 & 0.0009 & 0.386 & 9.52 & 0.930 \\
\hline 26 & Sajiwan & Jatrophacurcas & 8 & 0.0007 & 0.078 & 9.52 & 0.930 \\
\hline 27 & Kavro & Ficusinfectoria & 2 & 0.0001 & 0.154 & 14.28 & 1.395 \\
\hline 28 & Gijari & Premna spp. & 2 & 0.0001 & 0.145 & 9.52 & 0.930 \\
\hline 29 & Aasuro & Adhatodavasica & 4 & 0.0003 & 0.462 & 9.52 & 0.930 \\
\hline 30 & Simal & Bombaxceiba & 10 & 0.0009 & 0.386 & 23.80 & 2.325 \\
\hline 31 & Katus & Catanopsisindica & 1. & 0.00009 & 0.138 & 4.76 & 0.465 \\
\hline
\end{tabular}




\begin{tabular}{|c|c|c|c|c|c|c|c|}
\hline 32 & Jai Chilauni & & 2 & 0.0001 & 0.154 & 9.52 & 0.930 \\
\hline 33 & Chiuri & Aesandrabutyracea & 4 & 0.0003 & 0.462 & 9.52 & 0.930 \\
\hline 34 & Bad dhairo & $\begin{array}{l}\text { Lagerstroemia } \\
\text { parviflorus }\end{array}$ & 1 & 0.00009 & 0.138 & 4.76 & 0.465 \\
\hline 35 & Dhursu & Colobrokiaspp. & 11 & 0.0010 & 0.540 & 14.28 & 1.395 \\
\hline 36 & Khirro & Sapium insigne & 13 & 0.0012 & 0.848 & 19.04 & 1.860 \\
\hline 37 & Bar & Ficusbengalensis & 4 & 0.0003 & 0.462 & 19.04 & 1.860 \\
\hline 38 & Dumri & Ficusracemosa & 1 & 0.0009 & 0.138 & 4.76 & 0.465 \\
\hline 39 & Kemano & Careyaarborea & 7 & 0.0006 & 0.924 & 19.04 & 1.860 \\
\hline 40 & Goldarim & & 2 & 0.0001 & 0.154 & 9.52 & 0.930 \\
\hline 41 & Besare & & 1 & 0.00009 & 0.138 & 14.28 & 1.395 \\
\hline 42 & $\begin{array}{l}\text { Musure } \\
\text { Katus }\end{array}$ & Catanopsisindica & 4 & 0.0003 & 0.462 & 4.76 & 0.465 \\
\hline 43 & Bhote & & 1 & 0.00009 & 0.138 & 14.28 & 1.395 \\
\hline 44 & Bhogate & Citrus spp. & 6 & 0.0005 & 0.770 & 4.76 & 0.465 \\
\hline 45 & Sano gabajo & & 1 & 0.00009 & 0.138 & 9.52 & 0.930 \\
\hline 46 & Mallato & Macaranga spp. & 2 & 0.0001 & 0.154 & 9.52 & 0.930 \\
\hline 47 & Guyelo & & 4 & 0.0003 & 0.462 & 14.28 & 1.395 \\
\hline 48 & Ratpate & & 4 & 0.0003 & 0.462 & 14.28 & 1.395 \\
\hline 49 & Gayo & Bridelia retusa & 5 & 0.0004 & 0.616 & 9.52 & 0.930 \\
\hline 50 & Bel & Aeglemarmellos & 1 & 0.00009 & 0.138 & 9.52 & 0.930 \\
\hline 51 & Karjo & Sapium insigne & 4 & 0.0003 & 0.462 & 9.52 & 0.930 \\
\hline 52 & Githo & Discorea spp. & 2 & 0.0001 & 0.154 & 4.76 & 0.465 \\
\hline 53 & Niuwa & Citrus spp. & 5 & 0.0004 & 0.616 & 4.76 & 0.465 \\
\hline 54 & Teltapre & & 3 & 0.0002 & 0.308 & 9.52 & 0.930 \\
\hline 55 & Raju & & 3 & 0.0002 & 0.308 & 4.76 & 0.465 \\
\hline 56 & Ketuki & $\begin{array}{l}\text { Pandanus } \\
\text { Odoratissimus }\end{array}$ & 5 & 0.0004 & 0.616 & 9.52 & 0.930 \\
\hline 57 & $\begin{array}{l}\text { Aarari } \\
\text { Kanda }\end{array}$ & Acacia pinnata & 3 & 0.0002 & 0.308 & 4.76 & 0.465 \\
\hline 58 & Kaiyeu & Gravelliarobusta & 13 & 0.0012 & 0.848 & 9.52 & 0.930 \\
\hline Total & & & 716 & 0.06491 & & 1023.2 & \\
\hline
\end{tabular}

\section{DISCUSSION}

Four major behaviors were recorded in different field visiting time during the study period in which general behavior were recorded as foraging $47.25 \%$, moving $27.25 \%$, resting $14 \%$, and grooming $11.5 \%$ whereas Bhattarai (2002) recorded eating $29.20 \%$, sitting $33 \%$, walking $28.20 \%$, grooming $6.40 \%$, mating $1.1 \%$, aggregation $0.71 \%$ and play $0.40 \%$ in LNP, Chalise et al. (2005) recorded foraging $43.4 \%$, moving $31.7 \%$, sitting
$18.5 \%$, grooming $3.4 \%$ and stone licking $1.7 \%$ in the same Langtang National Park. Regmi (2008) recorded foraging $49 \%$, moving $26 \%$, resting $16 \%$ and grooming $9 \%$ in LNP. This similarity between LNP and this study site may be due to similar season and similar vegetation type. Chalise (2013) recorded foraging/eating $56 \%$, resting $19 \%$, locomotion $16 \%$, sleeping $12 \%$, grooming $6 \%$ and playing $1 \%$ in Shivapuri Nagarjun National Park, Adhikari \& Chalise (2014) recorded foraging 45\%, 
locomotion 25\%, resting 20\%, and Grooming 10\% and Pandey \& Chalise (2015) recorded $40 \%$ time in foraging/feeding, $21 \%$ time in locomotion, $16 \%$ time in grooming while $40 \%$ time inactive, $6 \%$ playing, and $1 \%$ sleeping in SNNP. The different in general behavior may be due to different season, food resources availability and day length as well.

The amount of time spent on locomotion is determined primarily by the distribution of food and food plant species in the habitat and by the nature of food items (Sarkar, 2000). Therefore, the Assamese Macaque had to allot 28\% time to locomotion similar result were recorded by Sarkar et al. (2012) in forest group of Assamese Macaque in Jokai reserved forest (RF) of Assam as 25\% time (range 23-26) for locomotion. Similarly, Chalise (2000a) recorded four major behaviors during the study in the both expeditions (1997/98) in MakaluBarun National Park taking geophagy into separate account and found 3 to $4 \%$ difference in case of feeding in his study (1997/98) invested 29/25\%. The present study showed that the Assamese Macaques spent $47 \%$ of their total time on feeding while Sarkar et al. (2012) showed that the forest group spend $40 \%$ of their total annual time (range $38-45$ ) on feeding. Chalise (2000b) found $47 / 44 \%$ which is 3 to $4 \%$ difference in case of feeding in his study (1997 to 1998) in Makalu Barun National Park. Adhikari \& Chalise (2014) recorded that the seasonal activity budget of Assamese Macaques in different four season as, $47 \%$ feeding in winter, $45 \%$ in pre monsoon, $44 \%$ in monsoon and $43 \%$ in post monsoon. They found $43 / 47 \%$ which is $4 \%$ difference in deeding on different four seasons. Higher time spent in locomotion, costs higher expenditure of energy. The Assamese Macaque which spent more time on locomotion had to spend more time in resting in order to make a balance of energy demand and supply. Hence the Macaca assamensis spent $14 \%$ of their total time in resting where different time spent was recorded by Sarkaret al. (2012) in resting for 13\% (range 7-20). Similarly Adhikari \& Chalise (2014) recorded that $21 \%$ time for resting in Lamjung whereas Pandey $\&$ Chalise (2015) reported that $14.95 \%$ resting in SNNP. Food resources are randomly distributed in the study area, individual of primate do not able to monopolize the resources. So, social tension due to aggregation is comparatively less in the forest group as compared to provision or temple group (Sarkar, 2000). Grooming behavior in long term serves the function of reducing "Social Tension" (Schino et al., 1988) and establishes a social bonding among the individual within the group (Kurland, 1977), so the Assamese Macaque spent only $10 \%$ of their total time on grooming in the present study. Whereas, Chopra et al. (1992) showed $14 \%$ in grooming by Rhesus Macaque, Bhattarai (2002) recorded grooming 29/25\%, Chaliseet al. (2005) recorded grooming 3-4\%, Regmi (2008) recorded grooming 9\%, Chalise (2013) recorded 6\% grooming, Adhikari \& Chalise (2014) found $10 \%$ grooming and Pandey \& Chalise (2015) reported that $16 \%$ in grooming. Hence, lacks of extra social tension in the Assamese Macaque due to its smaller size reduce the time spend on grooming.

Diurnal activities were recorded during March to May, 2016. A total of 16 individuals representing different age groups of focal aduwari troop of both the sexes were observed. The most common activity was feeding/foraging which was highest during $15 \mathrm{pm}$ to $18 \mathrm{pm}$ among the four periods i.e. $54 \%$ and lowest is during $12 \mathrm{am}$ to $15 \mathrm{pm}$. Time spent on moving was found to be highest from $12 \mathrm{am}$ to $15 \mathrm{pm}$ i.e. $33 \%$ and lowest $22 \%$ from $15 \mathrm{pm}$ to18pm. Time spent on resting was found highest $15 \%$ during $9 \mathrm{am}$ to $12 \mathrm{am}$ and lowest $13 \%$ at $15 \mathrm{pm}$ to $18 \mathrm{pm}$. Grooming was observed highest $13 \%$ at $12 \mathrm{am}$ to $15 \mathrm{pm}$ and lowest $10 \%$ from $15 \mathrm{pm}$ to $18 \mathrm{pm}$ where as Koirala \& Chalise (2014) reported from SNNP area time spent on feeding and foraging behavior was highest during 12 noon to $15 \mathrm{pm}$ among the four periods i.e. $46 \%$ and lowest was during $15 \mathrm{pm}$ to $18 \mathrm{pm}$ i.e. $33 \%$. Time spent on moving was too highest during $12 \mathrm{pm}-15 \mathrm{pm}$ i.e. $29 \%$ and lowest percentage of time spent on moving was during 9 am-12 noon i.e. $15 \%$. Between 12 noon - 15 pm macaques spent greater percentage of time on feeding and moving behavior so the time spent in resting and social behavior was lowest than other period i.e. $19 \%$ and $6 \%$ respectively the higher percentage of feeding during my study period might be due to lack of sufficient food on habitat. Due to newly constructed Kaligandaki corridor habitats of macaques are divided into several fragmented so the macaques spent more time for searching their own food.

Vegetation analysis was done by quadrate sampling recorded 58 plant species with 716 number. This study revealed that Sal (Sorea robusta) is the dominant plant species with relative density $31.42 \%$ and relative frequency $8.376 \%$ which is followed by Tiju (Diospyros malabarica) relative density $10.93 \%$ and relative frequency $8.376 \%$, with general behavior pattern recorded as foraging 
$47.25 \%$, moving $27.25 \%$, resting $14 \%$, and grooming $11.5 \%$ where as Aryal (2013) reported, from Arkhele and Nayagaun gulmi area by 8 quadrate of size $25 \mathrm{~m} \times 25 \mathrm{~m}$ quadrate sampling, 23 plant species with 191 number. According to his study, Khote Salla (Pinus ruxberghii) was the dominant plant species with relative density $30.89 \%$ and relative frequency $13.043 \%$ which was followed by Chilaune (Schima wallichi) with relative density $8.34 \%$ and relative frequency $10.87 \%$ with general behavior pattern of rhesus macaques recorded as foraging $47.25 \%$, moving $27.25 \%$, resting $14 \%$, and grooming $11.5 \%$. This different in general behavior pattern may be due to differentvegetation associated with their habitat. Due to differences in altitude range between these two study sites, two different types of dominant vegetation were found which directly affected the behavior pattern of monkey. Rijal (2014) recorded 27 plant species with 196 numbers at Nagarjun forest of SNNP by quadrate sampling. From his study Chilaune (Schima wallichi) was the dominant plant species with relative density $30.89 \%$ followed by Jhankrikath (Machilusduthiei) with relative density $8.98 \%$ and Masure katus (Castanopsis tribuloides) with relative frequency $10.87 \%$. In consistency with results of this findings altitudional variation causes the change in vegetation pattern which might have ultimately affected the general behavior pattern.

\section{CONCLUSION}

Total 47 individuals of Assamese Macaques were recorded from four troops at Kaligandaki River Basin, Baglung and Parbat Districts during the study period. The minimum of Assamese Macaques were reported from the Balewa Troop of Amalachaur VDC whereas maximum numbers of Assamese Macaques were reported in Aduwabari Troop of Chisti VDC. This study shows that general behavior of Assamese Macaques in different field visiting time in which the feeding activity has been found the major activity profile and minimum was grooming. Vegetation sampling, revealed that study area falls in the SoreaDiospyros zone.

\section{ACKNOWLEDGEMENTS}

Authors would like to acknowledge National Trust for Nature Conservation for providing research grant. We are thankful to Central Department of Zoology, Tribhuvan University for cooperation and Department of Forest Babarmahal for providing permission to conduct the research in the study area. We would like to thank to National Herbarium Center, Godawori, Lalitpur, IDEA wild USA and Mr. Bishnu Parsad Paudel for helping us identifying the scientific name of herbariums. Authors would like to extend sincere thanks to Dr. Ogawa, Professor, Faculty of Liberal Arts, Chukyo University, Japan for providing equipment needed for this research work. The authors are also grateful to Mr. Shivish Bhandari for his kind help. Sincere thanks are extended to local inhabitants for providing information about the Assamese Macaques.

\section{REFERENCES}

Adhikari, R. K. (2013). Population status, Distribution and General Behavior of Assamese Macaque (Macaca assamensis, McClelland, 1840) in Taghring and Ghermu VDCs, Lamjung Nepal. M. Sc. Thesis Central Department of Zoology, Tribhuvan University, Kathmandu, Nepal.

Adhikari, R. K. and Chalise, M. K. (2014). General Behavior of Assamese Monkey (Macaca assamansis, McClelland, 1840) at upper Marsyangdi area, Lamjung, Nepal. Special issue DNPWC-2071 84-93.

Altman, J. (1974). Observation of study of behavior: sampling methods. Behavior, 49: 227-265.

Aryal, K. (2012). Study of Ecology of monkey species and Crop depredation in Arkhale and Nayagaun, Gulmi, West Nepal. M. Sc. Thesis Central Department of Zoology, Tribhuvan University, Kathmandu, Nepal.

Bhattarai, B. R. (2002). General Behavior and Habitat use of Assamese Monkey (Macaca assamensis) in syafrubensi Area of Langtang National Park, Nepal. A Report submitted to IOF Pokhara, Nepal.

Chalise, M. K. (1997). Survey of primate in Makalu- Barun Conservation Area (Lower parts of Apsuwa, Isuwa and Sankhuwa River). A research report submitted to MBCA Project Nepal.

Chalise, M. K. (2000a). Report on the Assamese monkeys (Macaca assamensis) of Nepal. Asian Primate, 71-2: 7-11.

Chalise, M. K. (2000b). Behavior study of Assamese Monkey (Macaca assamensis) of Makalu Barun Area, Nepal In the Proceeding 
of IIIrd National Conference on Science and Technology, 2: 1323-1332.

Chalise, M. K. (2003). Assamese Monkeys (Macaca assamensis) in Nepal. Primate Conservation. The Journal of the IUCN/SSC Primate Specialist Group, Conservation International, USA, 19: 99-107.

Chalise, M. K.; Karki, J. B. and Ghimire M. K. (2005). Status in Nepal: Non-human Primate. In special issue of $10^{\text {th }}$ Wildlife Week, DNPWC, Nepal. 19-26.

Chalise, M. K. (2008). Primate Census in Kathmandu and West Parts of Nepal. Journal of Natural History Museum, 23: 60-64.

Chalise, M. K. (2011). Notes on Hanuman langurs and Assamese monkeys of Central Zoo, Nepal. Central Zoo Newsletter Quarterly Publication, 39: 3-4.

Chalise, M. K. (2013). Fragmented Primate Population of Nepal. In: Marsh L. K. and Chapman C. A. (eds) Primates in Fragments: Complexity and Resilience, Developments in Primatology: Progress and Prospects, pp 329-356.

Chopra, P. K.; Seth, S. and Seth, P. K. (1992). Behavioral Profile of Free-ranging Rhesus Monkey. Primate Report.

Jnawali, S. R.; Baral, H. S.; Lee, S.; Acharya, K. P.; Upadhyay, G. P.; Pandey, M. et al. (2011). The Status of Nepal Mammals: The National Red List Series. Department of National Parks and Wildlife Conservation, Kathmandu, Nepal.

Kawamoto, Y.; Aimi M. and Wangchuk, T. (2006). Distribution of Assamese macaques (Macaca assamensis) in the inner Himalayan region of Bhutan and their mtDNA diversity. Primates, 474: 388-392.

Koirala, S. and Chalise, M. K. (2014). Feeding Ecology of Assamese Macaque (Macaca assamensis) in Nagarjun Forest of Shivapuri Nagarjun National Park, Nepal. Nepalese Journal of Zoology, 21: 31-38.

Krebs, C. J. (1978). Ecology: The experimental analysis of distribution and abundance. $2^{\text {nd }}$ Ed. Harper and Row publishers.

Kurland, J. A. (1977). Kin Selection in Japanese monkey, Contribution to Primatology, 12.

Manning, A. and Dawkins, M. S. (1998). An Introduction of Animal Behavior. Cambridge University Press, Cambridge.
Martin, P. and Bateson P. (1993). Measuring Behavior. Cambridge University Press, Cambridge.

Medhi, R.; Chetry, D.; Choudhury, B. and Bhattacharjee, P. (2007). Status and diversity of temple primates in northeast India. Primate Conservation, 22:135-138.

Menon, V. (2003). A Field Guide to Indian Mammals 1: Dorling Kindersley (India) Pvt. Limited.

Pandey, B. P. and Chalise M. K. (2015). General ecology and time budgeting for Assamese Monkey (Macaca assamensis) in Shivapuri Nagarjun National Park, Nepal. Special issue, DNPWC-2072, 57-73. Nepal.

Paudel, P. K. (2016a). Population Status, Distribution and General Behavior of Assamese Monkey (Macaca assamensis McClelland, 1840) in Kaligandaki River Basin, Baglung and Parbat Districts, Nepal. M. Sc. Thesis. Central Department of Zoology, Tribhuvan University, Kathmandu, Nepal.

Paudel, P. K. (2016b). Conflict due to Assamese Macaques (Macaca assamensis McClelland, 1840) and crop protection strategiesin Kaligandaki River Basin, Western Nepal, Our Nature, 14: 107-114.

Paudel, P. K. (2016c). Assessment of conservation strategies for Human-Leopard conflict resolution in Kathmandu, Nepal. A final report submitted to D. F. O. Kathmandu Nepal.

Paudel, P. K. and Chalise M. K. (2016). Population Status of Assamese Macaques (Macaca assamensis McClelland, 1840) in Kaligandaki River Basin of Baglung and Parbat Districts, Nepal. Journal of Natural History Museum, (In Press).

Regmi, G. R. (2008). Status of Assamese Macaque (Macaque assamensis, McCland 1840) in Langtang National Park. M. Sc. Thesis Central Department of Zoology, Tribhuban University, Kathmandu Nepal.

Rijal, B. N. (2014). Ecological study of rhesus and Assamese Macaques and their conflict with humans in Nagarjun forest, Kathmandu, Nepal. M. Sc. thesis Central Department of Zoology, Tribhuvan University, Kathmandu Nepal.

Ross, C. and Reeve, N. (2003). Survey and census methods: Population distribution and 
density. In: J. M. Setchell and D. J. Curtis (eds) Field and Laboratory Methods in primatology. Cambridge, Cambridge University Press, pp. 90-109.

Sanjay, M.; Douglas, B. J.; Wolfgang, D.; Ardith, E.; Ajith, K.; Mewa, S. et al. (2003). Status of South Asian Primates: Conservation Assessment and Management Plan (CAMP) Workshop Report, Zoo Outreach Organization/CBSG-south Asia, Coimbatore, India, VIII, pp432.

Sarkar, P. (2000). Ecology and dynamic of social relationship of Assamese macaque (Macaca assamensis, McClland, 1840), Ph. D. Thesis. Guwahity University, Guwahity India.

Sarkar, P.; Srivastava, A.; Dasgupta, S. and Bhattacharjee, P. C. (2012). Activity profile of free ranging forest group of Assamese Macaque. The Clarion, 12: 59-67.
Schino, G.; Scucchi, S.; Maestipieri, D. and Turillazzi, P. G. (1988). All grooming as a tension reduction mechanism: A behavioral approach, 16: 43-50.

Timmins, R. J. and Duckworth, J. W. (2013). Distribution and Habitat of Assamese macaque (Macaca assamensis) in Lao PRD, Including its use of low-altitude Karsts. Primate conservation, 26:103-114.

Wada, K. (2005). The distribution pattern of Rhesus and Assamese Monkeys in Nepal. Primates, 46: 115-119.

Zobel, D. B.; Yadav, U. K.; Jha, P. K. and Behan, M. J. (1987). A practical manual for ecology. Rani printing press, Kathmandu, Nepal.

Zhou, Q.; Wei, H.; Huang, Z. and Huang, C. (2011). Diet of the Assamese Macaque (Macaca assamensis) in lime-stone habitats of Noggin, China. Current Zoology, 571: $18-25$. 